\title{
INTEGRASI AHP DAN SISTEM INFORMASI GEOGRAFIS UNTUK ANALISIS POTENSI KERAWANAN ILLEGAL FISHING DI INDONESIA Integration AHP and Geographic Information System to Analyse Vulnerability of Illegal Fishing in Indonesia
}

\author{
Moh. Dede ${ }^{1}$, Millary Agung Widiawaty ${ }^{1}$, Iwan Setiawan ${ }^{1}$, Nurul Huda ${ }^{2}$ \\ ${ }^{1}$ Departemen Pendidikan Geografi, FPIPS, Universitas Pendidikan Indonesia, Indonesia \\ ${ }^{2}$ SMA Negeri 1 Babakan, Kabupaten Cirebon, Indonesia \\ Email Korespondensi: m.dede.geo@gmail.com
}

DOI: $10.31314 /$ jsig.v2i2.253

Abstract - Indonesia is an archipelago state with large fishery resources and has a problem about illegal fishing from locally and internationally networks. Based on AHP and geographic information system, this study aims to analyse the spatial potention of illegal fishing in Indonesia involving various factors such as maritime patrol coverage, ocean sovereignty, distance from foreign country, chlorophyll-A distribution, and marine products richness which are validated with existing data, and the counter strategy. The illegal fishing modelling has an accuracy of 87.14 percent with a potential threat of 2,644,000 km2 (41.65 percent) including the North Natuna Sea, Malacca Strait, Karimata Strait, Java Sea, Makassar Strait, Bali Sea, Mollucas Sea, Halmahera Sea, Tomini Bay, Celebes Sea, and the small part of Arafuru Sea. The AHP result shows constant factor such marine products richness and chlorophyll-A distribution as the strongest criminogenic of illegal fishing in Indonesia. The efforts to prevent illegal fishing with interventions on dynamic factor. Strengthening maritime patrol coverage, VMS technology, community participation and maritime diplomation.

Keywords: AHP, GIS, illegal fishing, maritime axis.

\begin{abstract}
Abstrak -Indonesia merupakan negara kepulauan yang memiliki sumber daya perikanan melimpah dan kerap dijadikan sasaran illegal fishing jaringan lokal maupun internasional. Melalui integrasi AHP dan sistem informasi geografis, penelitian ini bertujuan untuk menganalisis potensi kerawanan illegal fishing secara spasial di Indonesia dengan melibatkan berbagai faktor penentunya seperti jangkauan patroli laut, kedaulatan laut, jarak dari negara asing, sebaran klorofil-A, dan potensi hasil laut yang divalidasi dengan data eksisting serta dilengkapi strategi penanganannya. Pemodelan illegal fishing memiliki akurasi sebesar 87,14 persen dengan potensi ancaman seluas $2.644 .000 \mathrm{~km} 2$ (41,65 persen) meliputi Laut Natuna Utara, Selat Malaka, Selat Karimata, Laut Jawa, Selat Makassar, Laut Bali, Laut Maluku, Laut Halmahera, Teluk Tomini, Laut Sulawesi, serta sebagian kecil Laut Arafuru. Hasil AHP menunjukkan faktor yang bersifat tetap seperti potensi laut dan sebaran klorofil-A sebagai criminogenic terkuat illegal fishing di Indonesia. Upaya pencegahan illegal fishing dapat dilakukan dengan intervensi terhadap faktor yang bersifat dinamis, sehingga memperkuat jangkauan patroli laut, teknologi VMS, partipasi masyarakat, dan diplomasi maritim
\end{abstract}

Kata kunci: AHP, illegal fishing, poros maritim, SIG 


\section{PENDAHULUAN}

Indonesia merupakan negara kepulauan terbesar yang memiliki biodiversitas tertinggi di dunia setelah Brazil. Biodiversitas tertinggi di lautan berada pada zona perairanan dangkal yang hangat dan tertembus oleh sinar matahari sebagai habitat esensisial bagi kehidupan beragam biota laut, khususnya organisme pelagik seperti plankton dan nekton, karena mampu menyumbangkan Rp342,66 triliun PDB (Hutabarat \& Evans, 2014; Fajar, 2018; FAO, 2014; KKP RI, 2015). Belum optimalnya pengelolaan dan pemanfataan sumber daya maritim turut menyebabkan kejadian 30 persen illegal fishing terjadi di perairan laut Indonesia (Belova, 2015)

Kerugian akibat illegal fishing mencapai Rp100 - Rp300 triliun per tahun, padahal sektor perikanan laut di sebagian besar wilayah pesisir Indonesia memiliki keunggulan komparatif yang dapat memicu pengembangan dan interaksi regional (Marlina \& Riza, 2013; Dede, Sewu, Yutika, \& Ramadhan, 2016). Maraknya kasus kejahatan illegal fishing disebabkan oleh berbagai faktor criminogenic baik yang bersifat pendorong (crime generator) maupun penarik (crime attractor) (Dede, Setiawan, \& Mulyadi, 2017; Dede \& Widiawaty, 2017). Berbagai faktor seperti dekatnya batas wilayah laut antar negara, minimnya kemampuan nelayan lokal dalam menangkap ikap, tingginya kapasitas kapal nelayan asing, lemahnya regulasi, dan belum optimanya penjagaan turut menjadi pertimbangan jaringan illegal fishing untuk beraksi di Indonesia (Jaelani \& Basuki, 2014). Penyebab illegal fishing juga dapat dicermati dari teori geography of crime, seperti kesesuaian target akses, pelaku yang termotivasi, serta uncapable guardian (Felson, 2006; Setiawan, Dede, Sugandi, \& Widiawaty, 2018).

Penanganan illegal fishing merupakan prioritas utama dalam mewujudkan cita-cita poros maritim (Pormar Indonesia, 2015). Penangangan secara preventif dapat dilakukan dengan mengkaji pola sebaran sumber daya perikanan dan kondisi lingkungan yang mempengaruhinya sebagai basis penentuan lokasi potensialnya (Ridho, Kaswadji, Jaya, \& Nurhakim, 2004). Penentuan kerawanan illegal fishing dapat divalidasi menggunakan data kasus pencurian ikan eksisting dari Badan Keamanaan Laut (Bakamla RI) melalui serangkaian uji statistic (Munaf \& Sulistyaningtyas, 2015).

Kajian komprehensif secara spasial terkait illegal fishing dapat dilakukan melalui integrasi analytical hierarchy processes (AHP) dan teknologi sistem informasi geografis (SIG), sehingga dihasilkan model spasial yang sesuai dengan dengan kerangka multi-criteria decision making (Martin, 2004; Widiawaty \& Dede, 2018). Tersedianya informasi terkait kerawanan illegal fishing secara spasial berguna bagi aparat berwenang Indonesia sebagai acuan dalam pengambilan keputusan terkait pengamanan sumber daya perikanan laut demi peningkatan kesejahetaraan dan mencapai cita-cita poros maritim. Oleh sebab itu, penelitian ini bertujuan untuk bentuk menganalisis potensi kerawanan illegal fishing di Indonesia melalui integrasi AHP dan SIG yang melibatkan faktor jangkauan patroli laut, kedaulatan laut, jarak dari negara asing, sebaran klorofilA, dan potensi hasil laut, serta strategi penanganannya.

\section{METODE DAN DATA Lokasi Kajian}

Kajian dalam penelitian ini meliputi seluruh wilayah perairan laut Negara Kesatuan Republik Indonesia yang terbagi atas 11 (sebelas) Wilayah Pengelolaan Perikanan Republik Indonesia (WPP RI) atau Fisheries Management Areas (FMA) yang telah ditetapkan oleh Kementerian Kelauatan dan Perikanan RI (Gambar 1). WPP RI meliputi Selat Malaka dan Laut Andaman (WPP 571), Samudera Hindia sebelah Barat Sumatera dan Selat Sunda (WPP 572), Samudera Hindia sebelah selatan Jawa hingga sebelah Selatan Nusa Tenggara dan Laut Timor bagian barat (WPP 573), Selat Karimata dan Laut Natuna Utara (WPP 711), Laut Jawa (WPP 712), Laut Flores hingga Selat Makasar (WPP 713), Teluk Tolo dan Laut Banda (WPP 714), Laut Seram hingga Teluk Tomini dan Laut Halmahera (WPP 716), Laut Sulawesi dan sebelah utara Pulau Halmahera (WPP 717), Teluk Cenderawasih dan Samudera Pasifik (WPP 718), serta Laut Arafuru hingga Laut Timor bagian Timur (WPP 715) (Suman, Wudianto, Sumiono, Badrudin, \& Nugroho, 2014). 


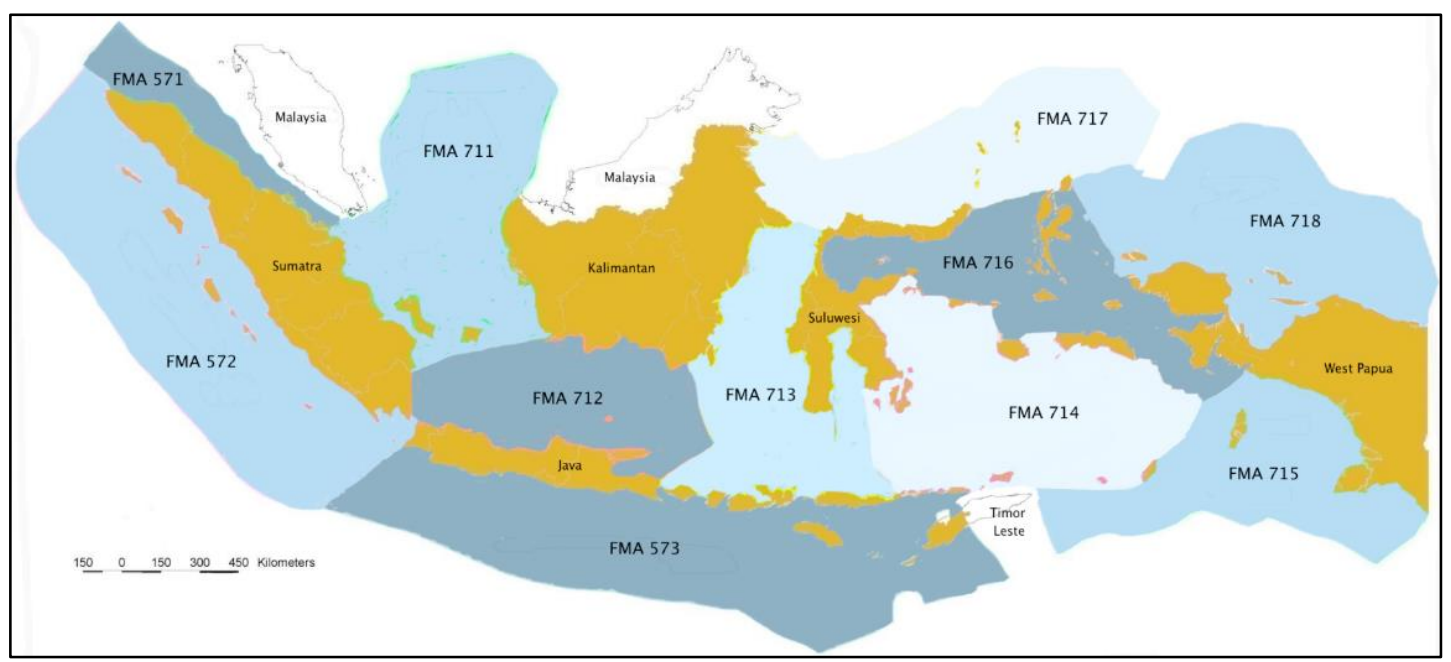

Gambar 1. Lokasi Kajian (Sumber: KKP RI, 2014; Hermes, 2014)

\section{Akuisisi dan Analisis Data Penelitian}

Ilegal fishing terjadi akibat ketimpangan antara supply dan demand sumber daya perikanan, dimana sebanyak 65 - 85 persen tindakan illegal fishing di Indonesia dilakukan oleh kapal asing (Sutardi, 2015). Pada penelitian ini, faktor penyebab illegal fishing yang digunakan dalam analisis AHP meliputi jangkauan patroli laut, kedaulatan laut, jarak dari negara asing, sebaran klorofil-A, dan potensi hasil laut (lihat Tabel 1).

Tabel 1. Akuisisi Data (Sumber: Hasil Analisis, 2018)

\begin{tabular}{|c|c|c|}
\hline $\begin{array}{l}\text { Faktor Penyebab } \\
\text { Illegal Fishing }\end{array}$ & Rasionalisasi & Sumber Data \\
\hline Jangkauan patroli laut & $\begin{array}{l}\text { Jangkauan patroli aparat keamanan laut } \\
\text { dari markas komando terdekat. }\end{array}$ & $\begin{array}{l}\text { Badan Keamanan Laut } \\
\text { (Bakamla) RI }\end{array}$ \\
\hline Kedaulatan laut & $\begin{array}{l}\text { Wilayah laut Indonesia terbagi atas Laut } \\
\text { Teritorial, Landasan Kontinen, dan ZEE }\end{array}$ & $\begin{array}{l}\text { Badan Informasi } \\
\text { Geospasial (BIG) }\end{array}$ \\
\hline Sebaran klorofil-A & $\begin{array}{l}\text { Klorofil-A merupakan zat pada } \\
\text { fitoplankton (produsen) yang dapat } \\
\text { terdeteksi oleh citra satelit secara berkala. }\end{array}$ & $\begin{array}{l}\text { Lembaga Antariksa } \\
\text { dan Penerbangan } \\
\text { Nasional (LAPAN) }\end{array}$ \\
\hline Potensi hasil laut & $\begin{array}{l}\text { Hasil laut (organisme pelagis) tahunan } \\
\text { dalam satuan ton di tiap WPP RI. }\end{array}$ & $\begin{array}{l}\text { Kementrian Kelautan } \\
\text { dan Perikanan } \\
\text { (KKP RI) }\end{array}$ \\
\hline Jarak dari negara asing & $\begin{array}{l}\text { Jangkauan kapal asing (rata-rata } \\
\text { berukuran } 100 \text { Gross Ton) yang } \\
\text { dipengaruhi oleh keberadaan pelabuhan } \\
\text { (daratan) di negara asing. }\end{array}$ & $\begin{array}{l}\text { Badan Informasi } \\
\text { Geospasial (BIG) }\end{array}$ \\
\hline
\end{tabular}

Penelitian ini menggunakan pendekatan mixed methods yang menggabungkan analisis kualitatif dan kuantitatif. Berbagai faktor tersebut harus melalui serangkaian tahap sebagai bagian dari multi-criteria decision making yang meliputi 1) identifikasi, 2) penyusunan hierarki, 3) pembuatan matriks perbandingan, 4) melakukan perbandingan berpasangan (normalisasi), 5) komparasi bobot, serta 6) pemeriksaan konsitensi. Evaluasi terhadap faktor-faktor penyebab illegal fishing dilakukan dengan mempertimbangkan struktur hierarki, validitas, dan inkonsistensi yang dipilih oleh pengambil keputusan (Makkasau, 2012).

Nilai bobot yang telah valid dan konsisten dapat digunakan sebagai pembobot numerik dalam analisis spasial dengan menggunakan analisis overlay melalui perangkat lunak SIG (Widiawaty, Dede, \& Ismail, 2018). Potensi kerawanan illegal fishing secara spasial tersebut harus melalui uji statistik (korelasi) yang disesuaikan dengan kriteria dan data eksisting, sehingga diperoleh nilai signifikansinya (Dede, Sugandi, \& Setiawan, 2018). Selengkapnya mengenai rangkaian analisis data penelitian tersaji pada Gambar 2. 


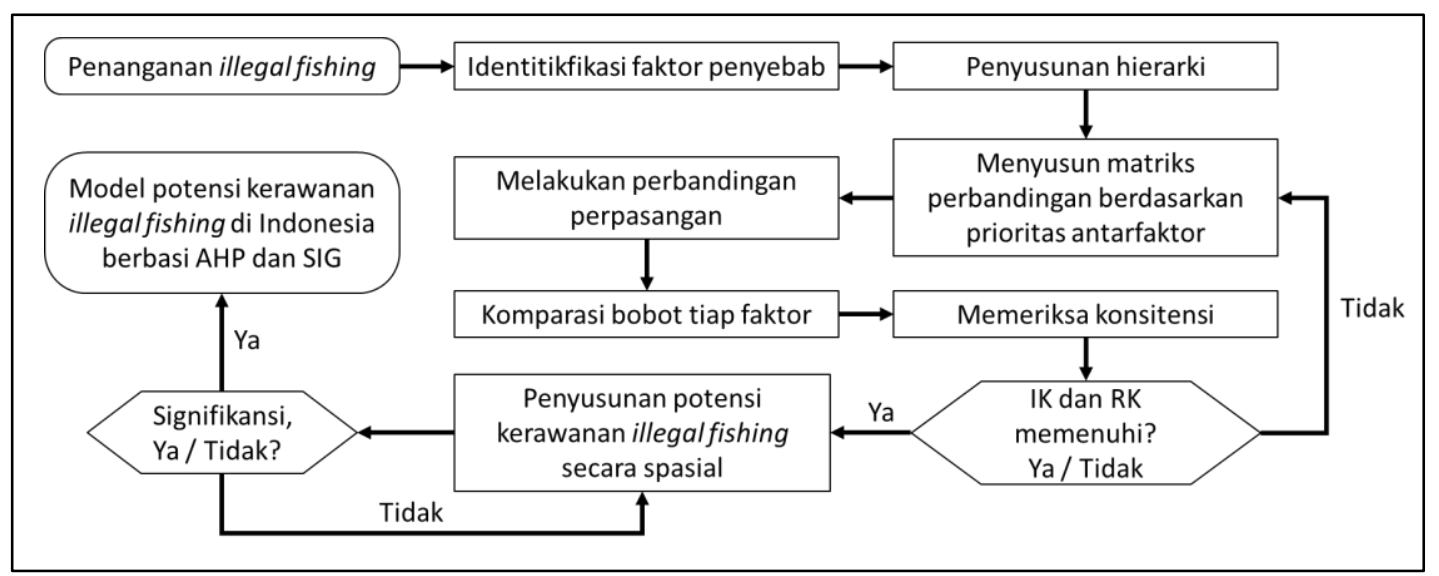

Gambar 2. Kerangka Analisis (Sumber: Analisis Penulis, 2018).

\section{HASIL DAN PEMBAHASAN}

\section{Analisis Berbagai Faktor Penyebab Illegal Fishing}

Penafsiran terhadap (lima) parameter penyebab illegal fishing terbagi atas crime generator dan penarik crime attractor yang disesuaikan pula dengan kondisi geografis Indonesia. pembobotan variabel illegal fishing menggunakan AHP diawali pada tahap indentifikasi faktor penyebab. Pada tahap ini, berbagai faktor penyebab illegal fishing perlu dilakukan upaya coding dalam bentuk matriks identifikasi demi memudahkan tahapan analisis selanjutnya (lihat Tabel 2).

Tabel 2. Identifikasi Berbagai Faktor Penyebab Illegal Fishing.

\begin{tabular}{lccc}
\multicolumn{1}{c}{ Parameter } & \multirow{2}{*}{ Kode } & \multicolumn{2}{c}{ Faktor Penyebab } \\
& & Crime Generator & Crime Attractor \\
\hline Jangkauan patroli laut & JP & Ya & - \\
Kedaulatan laut & KL & Ya & - \\
Klorofil-A & KA & - & Ya \\
Potensi hasil laut & PL & - & Ya \\
Jarak dari negara asing & JN & Ya & - \\
\hline
\end{tabular}

Penyebab illegal fishing yang tergolong dalam crime attractor terdiri atas 3 (tiga) faktor meliputi jangkauan patroli laut, kedaulatan laut, dan jarak dari negara asing. Sementara dari sisi crime attractor hanya terdiri dari 2 (dua) faktor yakni klorofil-A dan potensi hasil laut. Setelah tahap identifikasi, penyusnan hierarki dilakukan untuk mengetahui interaksi antar berbagai faktor yang mempengaruhi illegal fishing secara komprehensif dan saling berkaitan seperti pada Gambar berikut:

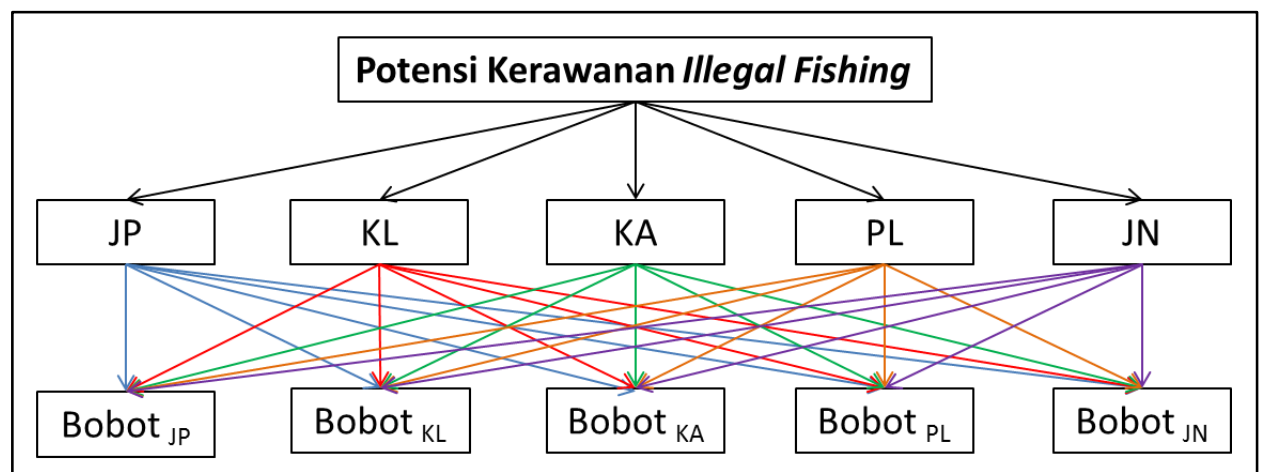

Gambar 3. Hierarki AHP Illegal Fishing (Sumber: Hasil Analisis, 2018).

Keterkaitan berbagai faktor illegal fishing dapat ditentukan nilai prioritasnya menggunakan matriks perbandingan yang pada bagian terbawah terdapat baris dari hasil penjumlahan secara vertikal (lihat Tabel 3). Nilai prioritas tersebut mengacu pada kekuatan masing-masing faktor terhadap illegal fishing melalui telaah yang mendalam dari hasil kajian dan informasi sebelumnya. 
Tabel 3. Prioritas Antar Parameter (Sumber: Hasil Analisis, 2018).

\begin{tabular}{cccccc}
\hline $\begin{array}{c}\text { Faktor Penyebab } \\
\text { Illegal Fishing }\end{array}$ & KL & JP & JN & PL & KA \\
\hline KL & 1,000 & 0,800 & 0,600 & 0,250 & 0,200 \\
JP & 1,250 & 1,000 & 0,300 & 0,500 & 0,320 \\
JN & 1,670 & 3,333 & 1,000 & 0,750 & 0,400 \\
PL & 4,000 & 2,000 & 1,333 & 1,000 & 0,500 \\
KA & 4,000 & 3,125 & 2,500 & 2,000 & 1,000 \\
\hline Jumlah & 11,920 & 10,255 & 5,730 & 4,500 & 2,420
\end{tabular}

Berbasis nilai prioritas tiap faktor pada Tabel 3, tahapan analisis untuk memperoleh nilai pembobot (weighting) AHP berlanjut ke tahap perbandingan berpasangan (normalisasi). Di tahap ini, nilai prioritas tiap faktor harus dibagi dengan hasil penjumlahan kolomnya. Pada Tabel 4, nilai KL diperoleh sebagai dari 1 dibagi 11,92. Bila operasi matematis ini telah selesai, maka perlu dibuat kolom rerata secara mendatar pada bagian sebelah kanan sebagai nilai normalisasi yang nantinya akan digunakan sebagai acuan untuk komparasi bobot. Bila proses AHP dinyatakan valid, maka nilai rerata pada Tabel 4 dapat digunakan sebagai pembobot dalam analisis spasial.

Tabel 4. Normalisasi Tiap Faktor (Sumber: Hasil Analisis, 2018).

\begin{tabular}{ccrrccc}
\hline $\begin{array}{c}\text { Faktor Penyebab } \\
\text { Illegal Fishing }\end{array}$ & \multicolumn{1}{c}{ KL } & \multicolumn{1}{c}{ JP } & \multicolumn{1}{c}{ JN } & \multicolumn{1}{c}{ PL } & KA & Rerata \\
\hline KL & 0.077399 & 0.078011 & 0.104712 & 0.055556 & 0.082645 & 0.079664 \\
JP & 0.096749 & 0.097513 & 0.052356 & 0.111111 & 0.132231 & 0.097992 \\
JN & 0.129257 & 0.32472 & 0.17452 & 0.166667 & 0.165289 & 0.192091 \\
PL & 0.309598 & 0.195027 & 0.232112 & 0.222222 & 0.206612 & 0.233114 \\
KA & 0.386997 & 0.304729 & 0.4363 & 0.4444444 & 0.413223 & 0.397139 \\
\hline
\end{tabular}

Komparasi bobot dilakukan melalui bobot setiap faktor dengan nilai rata-rata hasil normalisasi. Hasil dari proses tersebut kemudian dijumlahkan secara mendatar seperti yang tersaji pada Tabel 5. Nilai rerata dan penjumlahan tersebut dapat digunakan untuk uji (pemerikasaan) konsistensi bobot.

Tabel 5. Komparasi Bobot Tiap Faktor (Sumber: Hasil Analisis, 2018).

\begin{tabular}{ccccccc}
\hline $\begin{array}{c}\text { Faktor Penyebab } \\
\text { Illegal Fishing }\end{array}$ & KL & JP & JN & PL & KA & Jumlah \\
\hline KL & 0.079664 & 0.078394 & 0.115254 & 0.058278 & 0.079428 & 0.411019 \\
JP & 0.099581 & 0.097992 & 0.057627 & 0.116557 & 0.127084 & 0.498841 \\
JN & 0.133040 & 0.326314 & 0.192091 & 0.174835 & 0.158856 & 0.985135 \\
PL & 0.318658 & 0.195984 & 0.255480 & 0.233114 & 0.198569 & 1.201806 \\
KA & 0.398322 & 0.306226 & 0.480226 & 0.466228 & 0.397139 & 2.048141 \\
\hline
\end{tabular}

Pengukuran konsistensi antarbobot dilakukan dengan menghitung indeks konsistensi (IK) dan rasio konsitensi (RK), kedua nilai tersebut dapat ditemukan bila consistency vector $(\mathrm{Cv})$ untuk tiap faktor telah diperoleh. $C v$ didapatkan dengan cara membagi jumlah dengan rerata yang terdapat pada Tabel 4 dan 5, sehingga diperoleh hasil seperti tertera pada Tabel 6.

Tabel 6. Consistency Vector (Sumber: Hasil Analisis, 2018).

\begin{tabular}{cc}
\hline Faktor Penyebab Illegal Fishing & Consistency Vector \\
\hline KL & 5,159374541 \\
JP & 5,090621521 \\
JN & 5,128495210 \\
PL & 5,155444462 \\
KA & 5,138235621 \\
$\kappa(l a m b d a)$ & 5,138235621 \\
\hline
\end{tabular}


Consistency vector tiap faktor penyebab illegal fishing memiliki nilai rerata yang dinyatakan dalam lambda $(K)$ sebesar 5,139 (telah dibulatkan). Selain $K$, IK dan RK juga memerlukan nilai rasio acak diperoleh berdasarkan AHP's random index yang disesuaikan dengan jumlah faktor penentu. Pada penelitian ini rasio acak diketahui sebesar 1,12 (n=5). Perhitungan nilai IK maupun RK dilakukan dengan menggunakan dua persamaan sebagai berikut.

$$
\begin{aligned}
& \mathrm{IK}=(K-5) /(\mathrm{n}-1) \\
& \mathrm{RK}=\mathrm{IK} / \text { nilai rasio acak }
\end{aligned}
$$

Melalui persamaan tersebut diketahui bahwa nilai IK sebesar 0,035 dengan RK yang mencapai 0,031. Kedua nilai tersebut dinyatatakan valid karena bernilai $<0,1$. Oleh sebab itu, pembobot untuk tiap faktor penyebab illegal fishing di Indonesia dinyatakan valid serta layak dengan jumlah potensi laut dan sebaran klorofil-A sebagai yang tertinggi.

\begin{tabular}{|c|c|c|c|c|c|}
\hline $\begin{array}{c}\text { Faktor } \\
\text { Penyebab }\end{array}$ & $\begin{array}{c}\text { Metode } \\
\text { Pengharkatan }\end{array}$ & \multicolumn{2}{|l|}{ Harkat } & Bobot & Keterangan \\
\hline \multirow[t]{2}{*}{ JP } & Biner & Terjangkau & 1,00 & 0.09799 & $\begin{array}{l}\text { Terjangkau kapal patroli hingga } 200 \\
\text { mil laut }\end{array}$ \\
\hline & & $\begin{array}{l}\text { Tidak } \\
\text { Terjangkau }\end{array}$ & 0,00 & & $\begin{array}{l}\text { Tidak terjangkau patroli hingga } 200 \\
\text { mil laut }\end{array}$ \\
\hline \multirow[t]{2}{*}{ KL } & Perbandingan & ZEE & 2,20 & 0.07966 & Luas ZEE mencapai $2.944 .000 \mathrm{~km}^{2}$ \\
\hline & & Laut Teritorial & 1,90 & & Luas Laut Teritorial $3.401 .000 \mathrm{~km}^{2}$ \\
\hline \multirow[t]{2}{*}{$\mathrm{JN}$} & Biner & Terjangkau & 1,00 & 0,19209 & $\begin{array}{l}\text { Jarak tempuh minimal kapal } 100 \mathrm{GT} \\
\text { negara lain }\end{array}$ \\
\hline & & $\begin{array}{l}\text { Tidak } \\
\text { Terjangkau }\end{array}$ & 0,00 & & $\begin{array}{l}\text { Jarak tempuh minimal kapal } 100 \text { GT } \\
\text { negara lain }\end{array}$ \\
\hline \multirow[t]{3}{*}{ KA } & Perbandingan & Melimpah & 0,43 & 0.39714 & $\begin{array}{l}\text { Konsentrasi klorofil-A } 27,3-34,5 \\
\mathrm{mg} / \mathrm{l}\end{array}$ \\
\hline & & Menegah & 0,34 & & $\begin{array}{l}\text { Konsentrasi klorofil-A } 18,9-27,2 \\
\mathrm{mg} / \mathrm{l}\end{array}$ \\
\hline & & Sedikit & 0,23 & & Konsentrasi klorofil-A $0-18,8 \mathrm{mg} / \mathrm{l}$ \\
\hline \multirow[t]{5}{*}{ PL } & Kuantil & Sangat Banyak & 5,00 & 0.23311 & $\begin{array}{l}\text { Lebih dari atau sama dengan } 1.924 \\
\text { ton } / \mathrm{km}^{2} / \text { tahun }\end{array}$ \\
\hline & & Banyak & 4,00 & & $1.666-1.923,99$ ton $/ \mathrm{km}^{2} /$ tahun \\
\hline & & Sedang & 3,00 & & $761-1.655,99$ ton $/ \mathrm{km}^{2} /$ tahun \\
\hline & & Sedikit & 2,00 & & $516-760,99$ ton $/ \mathrm{km}^{2} /$ tahun \\
\hline & & Sangat Sedikit & 1,00 & & Kurang dari 516 ton $/ \mathrm{km}^{2} /$ tahun \\
\hline
\end{tabular}

Tabel 7. Pengharkatan Tiap Faktor Penyebab Illegal Fishing (Sumber: Hasil Analisis, 2018)

\section{Potensi Kerawanan Illegal Fishing di Indonesia berbasis AHP dan SIG}

Setelah menentukan bobot untuk masing-masing faktor penyebab illegal fishing, upaya selanjutnya adalah penentuan harkat. Pengharkatan dilakukan berdasarkan karakteristik tiap faktor yang berbeda. Pengharkatan ini terbagi atas tiga metode yakni kuantil, biner, dan perbandingan. Metode kuantil dipilih jika data memiliki distribusi yang beragam dan dapat diklasifikasikan menjadi lima kelas yang sama besar, sedangkan metode biner digunakan bila data hanya memiliki dua kategori yang salah satunya menjadi tidak bernilai atau nol. Sementara metode perbandingan dipakai bila data terbagi atas dua kategori bernilai riil. Informasi detail mengenai pengharkatan tersaji pada Tabel 7.

Harkat dari tiap faktor tersebut dapat digunakan sebagai pelengkap kriteria dalam menyusun dataset spasial penyebab illegal fishing di Indonesia (lihat Gambar 4). Potensi kerawanan illegal fishing secara spasial diperoleh melalui penggabungan atribut numerik (overlay tipe union), nilainya dididasari oleh bobot dan harkat yang telah disusun sebelumnya seperti pada Gambar 5.

Pemodelan potensi kerawanan illegal fishing yang disusun dengan menggunakan berbagai faktor tersebut menunjukkan sebarannya berada di wilayah perairan Laut Natuna Utara, Selat Malaka, Selat Karimata, Laut Jawa, Selat Makassar, Teluk Tomini, Laut Bali, Laut Maluku,Laut Flores, Laut Halmahera, Laut Sulawesi, serta sebagian kecil Laut Arafuru (lihat Gambar 7). Bila 
dijumlahkan, total wilayah perairan laut Indonesia yang berpotensi rawan illegal fishing mencapai $2.644 .000 \mathrm{~km}^{2}$ atau 41,65 persen, dimana 78,04\% berada di wilayah laut teritorial

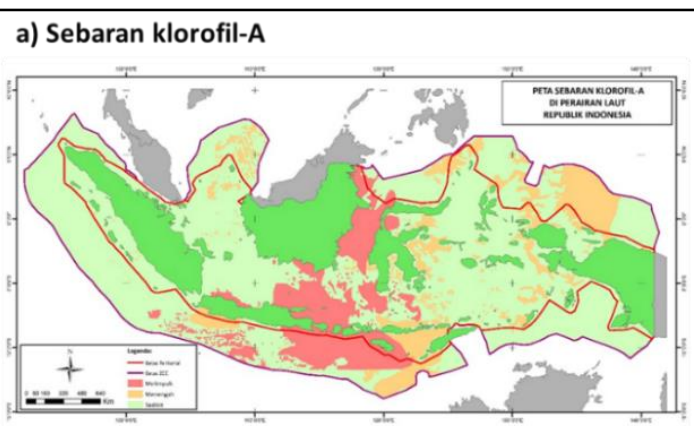

c) Jarak dari negara asing

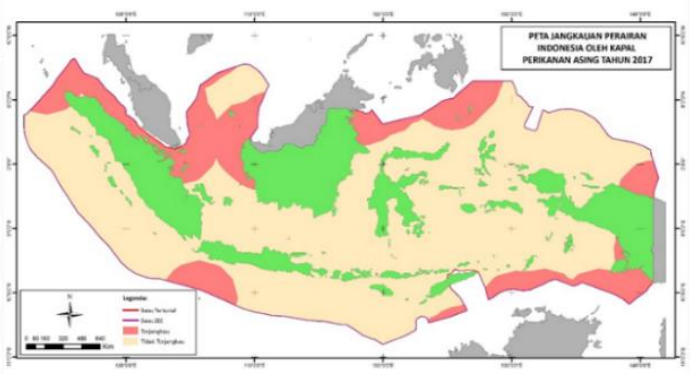

e) Jangkauan patroli laut

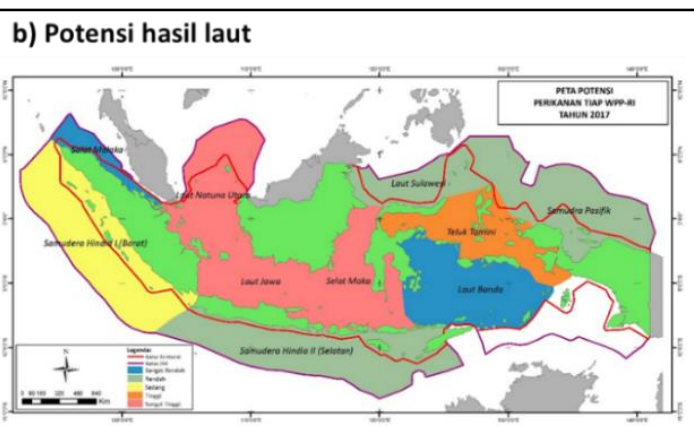

d) Kedaulatan laut

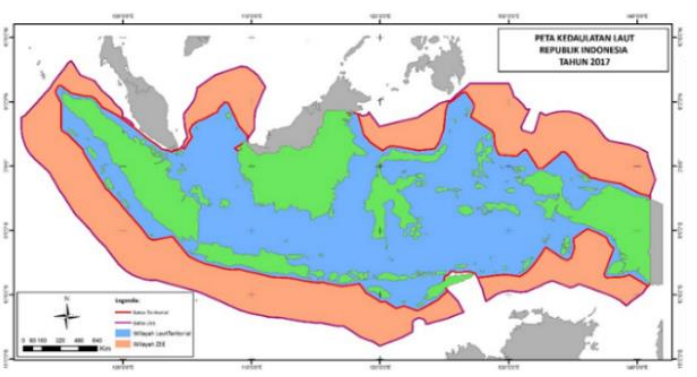

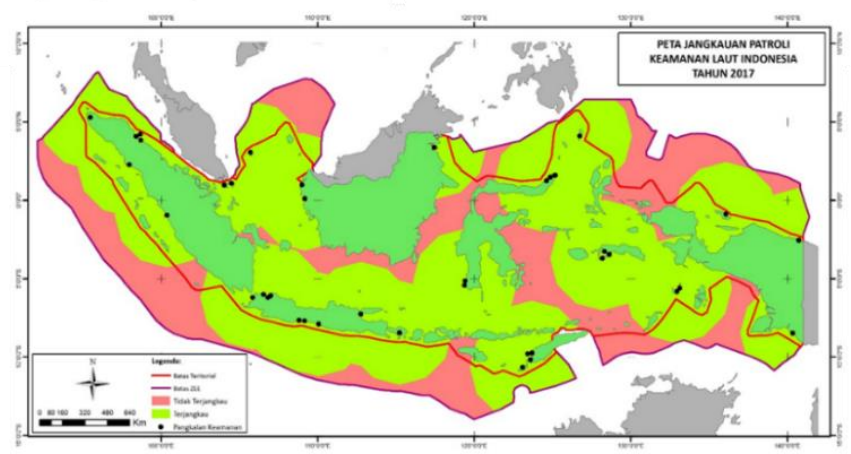

Gambar 5. Peta Faktor-Faktor Penyebab Illegal Fishing di Indonesia (Hasil Analisis, 2018).

Sebagai sebuah model geografis, pemodelan illegal fishing harus diverifikasi menggunakan data eksisting dari pihak berwenang dengan prosedur uji korelasi yang dibagi dalam unit geografis berupa Alur Laut Kepulauan Indonesia (ALKI). Pemodelan spasial ini memiliki korelasi sebesar 0,867 dan determinasi 75 persen yang mana nilainya dinyatakan signifikan dengan taraf kepercayaan 99 persen.

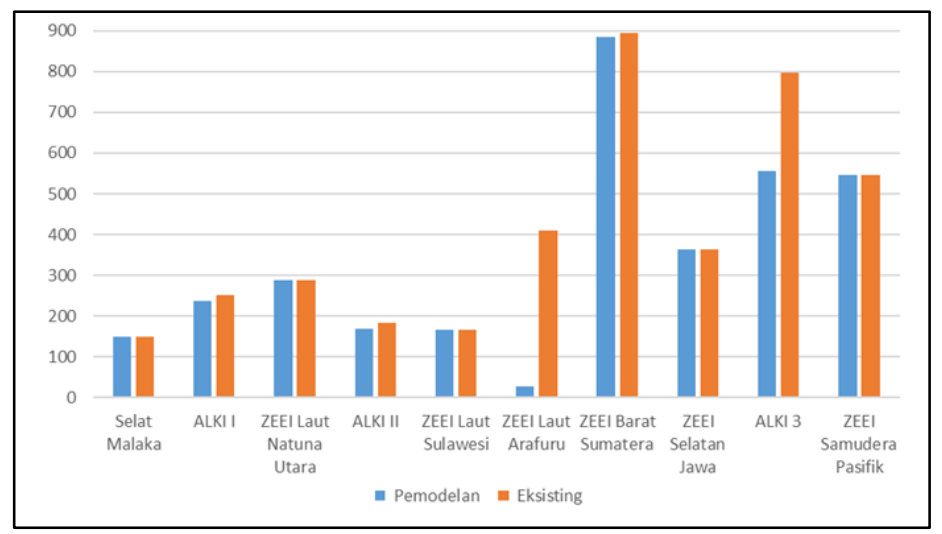

Gambar 6. Perbandingan Kerawanan Illegal Fishing Hasil Pemodelan dan Eksisting (Sumber: Hasil Analisis, 2018). 


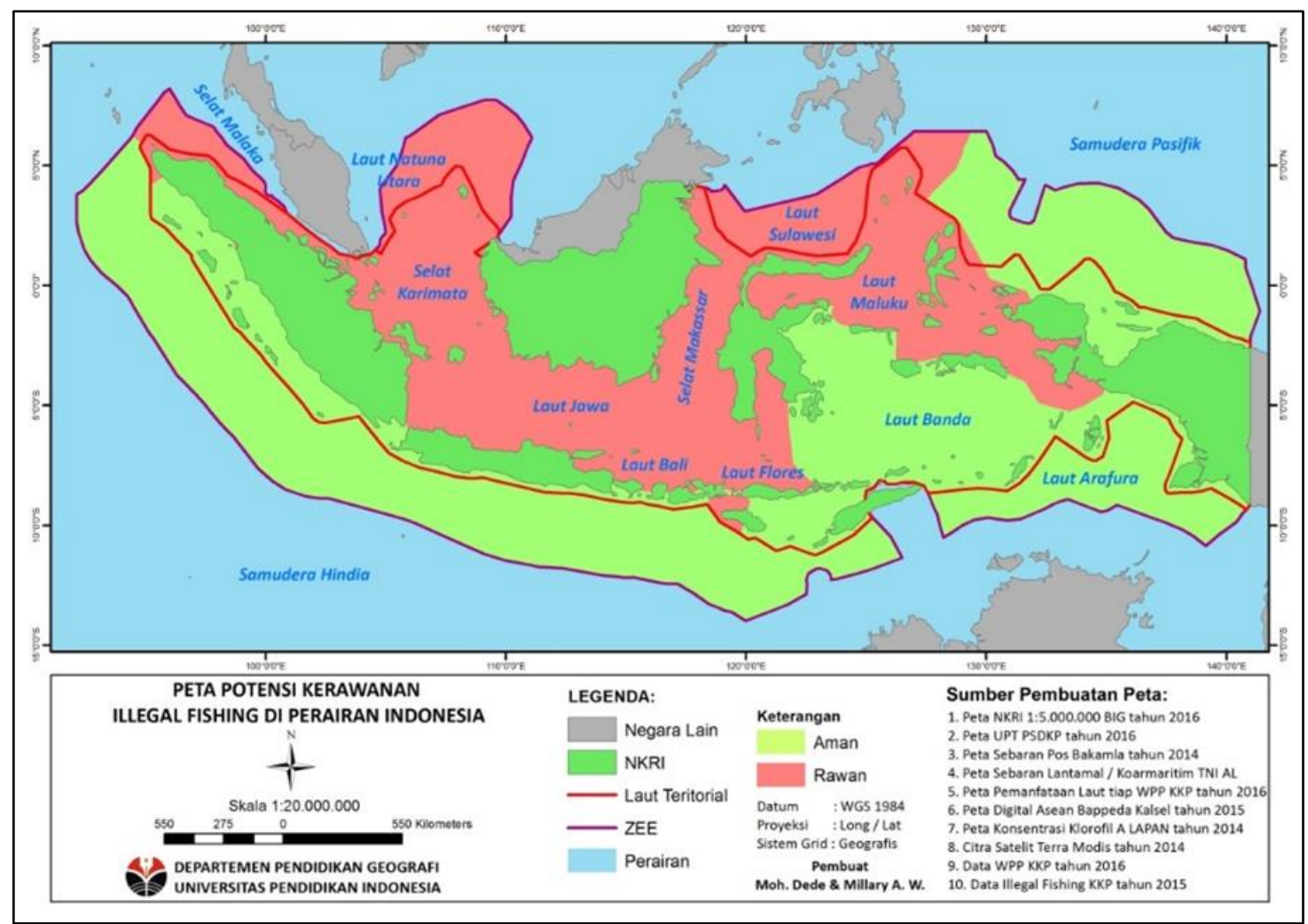

Gambar 7. Potensi Kerawanan Illegal Fishing di Indonesia (Hasil Analisis, 2018)

Adanya hasil tersebut menunjukkan bahwa pemodelan potensi kerawanan illegal fishing menggunakan AHP dan SIG terbukti bisa dilakukan, meskipun terdapat faktor penyebab lain (epsilon) hingga 25 persen. Perbandingan luas wilayah rawan illegal fishing hasil pemodelan maupun eksisting tersaji pada Gambar 6.

\section{Strategi Penanganan Illegal Fishing di Indonesia}

Hasil analisis AHP menunjukkan hanya terdapat satu faktor dinamis yaitu jangkauan patroli laut yang masih terbatas. Kelemahan ini disebabkan oleh terbatasnya anggaran bahan bakar minyak (BBM) yang hanya 32\% dari total kebutuhan kapal patroli, jumlah kapal patroli yang belum memadai, dan teknologi pendeketeksian kapal yang terbatas. Oleh sebab itu, strategi penanggulangan illegal fishing yang pertama adalah penguatan armada keamanan laut agar uncapable guardian tidak terjadi. Sedangkan faktor lain seperti jarak dari negara asing, sebaran klorofil-A, potensi laut, dan kedaulatan laut merupakan parameter yang bersifat tetap karena dipengaruhi oleh kondisi lingkungan (lihat Gambar 8).

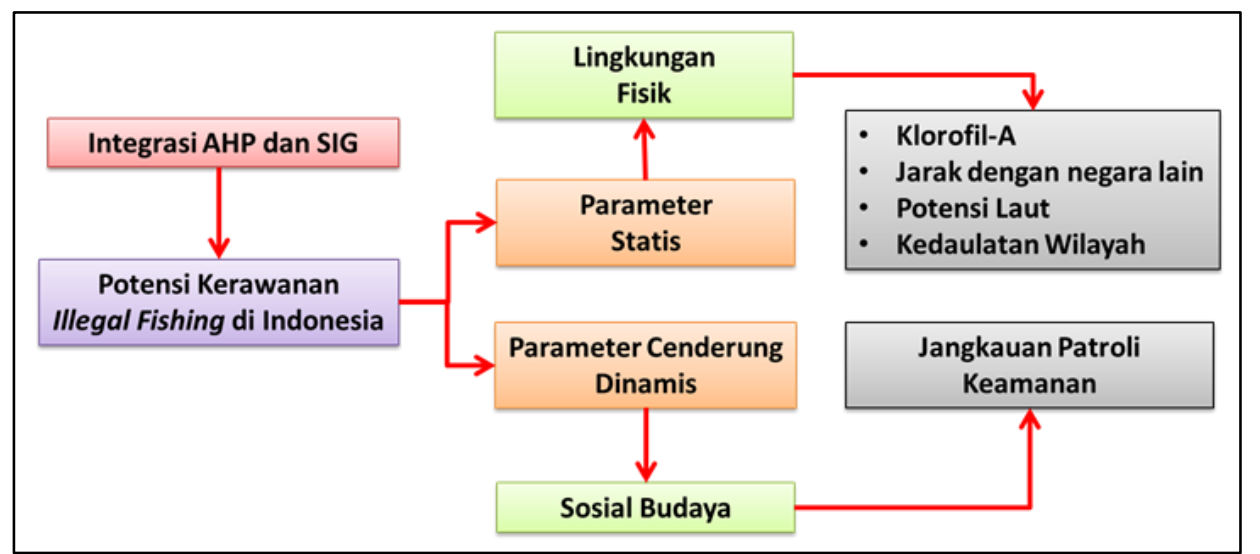

Gambar 8. Faktor Statis dan Dinamis Penyebab Illegal Fishing (Sumber: Hasil Analisis, 2018)

Wilayah perairan yang dekat dengan negara lain mempunyai potensi kerawanan illegal fishing yang lebih besar dari pada wilayah lainnya, sehingga upaya yang efisien dalam 
menanggulanginya yakni melalui penggunaan teknologi informasi geografis seperti Vessel Monitoring System (VMS). Teknologi ini mampu mendeteksi keberadaan kapal penangkap ikan secara real-time karena berbasis pada GNSS. Kapal penangkap ikan skala menengah hingga besar memiliki perangkat navigasi yang dapat terdeteksi oleh VMS. Upaya lain yang dapat ditempuh yakni pemberdayaan nelayan setempat melalui kegiatan pelaporan dini yang berbasis mobile. Kedua upaya ini dapat berjalan dengan baik bila penindakan dari aparat keamanan tepat dilakukan.

Selain penindakkan secara internal, upaya penanggulangan illegal fishing dapat ditempuh dengan diplomasi internasional. Penguatan diplomasi dapat mencegah illegal fishing dari negara asal pelaku, karena sebagian besar illegal fishing di perairan Indonesia berasal dari negara-negara tetangga seperti Thailand, Vietnam, Malaysia, Filipina, dan Tiongkok.

\section{KESIMPULAN}

Integrasi AHP dan SIG menemukan bahwa potensi laut dan sebaran klorofil-A sebagai faktor penyebab tertinggi fenomena illegal fihing di Indonesia. Semua faktor penarik terbukti mempengaruhi pertimbangan para pelaku illegal fishing. Lokasi potensial kerawanan illegal fishing hasil pemodelan mencapai 41,65 persen dengan validitas mencapai 0,867. Upaya penanggulanganya dapat dilakukan dengan menintervensi faktor dinamis seperti memperkuat jangkauan patroli laut, teknologi VMS, hingga partipasi masyarakat. Penelitian spasial terhadap fenomena illegal fishing dapat diperkuat melalui pemanfataan data koordinat lokasi (titik) TKP kejahatan tersebut sebagai bagian dari pengembangan sains maritim. Upaya ini berguna untuk mengetahui densitas illegal fishing per satuan WPP RI dan bermanfaat dalam penenetuan lokasi prioritas patroli keamanaan laut secara detail.

\section{DAFTAR PUSTAKA}

Belova, G. (2015). Illegal Unreported and Unregulated Fishing in The Black Sea. International Conference Knowledge - Based Organization, $21 \quad$ (2), 408-412. https://doi.org/10.1515/kbo-2015-0069.

Dede, M., Setiawan, I., \& Mulyadi, A. (2017). Application GIS to Analyse Crime Risk in Bandung. Proceeding The 2nd UPI International Conference on Sociology Education, 1 (1), 597-602. https://doi.org/10.5220/0007102605970602.

Dede, M., Sewu, R. S. B., Yutika, M., \& Ramadhan, F. (2016). Analisis Potensi Perekonomian Sektor Pertanian, Kehutanan, dan Perikanan serta Pertambangan dan Penggalian di Pantura Jawa Barat. Seminar Nasional Epicentrum 5.5: Optimalisasi Sumber Daya Alam Matra Darat Dan Matra Lautan Untuk Ketahanan Pangan dan Kesehatan Dalam Konteks Nasionalisme, 1 (1), 100-108. https://doi.org/10.17605/OSF.IO/MC2T6.

Dede, M., Sugandi, D., \& Setiawan, I. (2018). Pengaruh Kondisi Lingkungan Terhadap Kerawanan Kejahatan di Kawasan Perkotaan Studi Kasus di Kecamatan Sumur Bandung, Kota Bandung. Seminar Nasional Geomatika, 3, 555-564. https://doi.org/10.24895/SNG.2018.3-0.1009.

Dede, M., \& Widiawaty, M. A. (2017). Mewujudkan Pemanfaatan Sistem Informasi Geografis untuk Pencegahan Kriminalitas di Indonesia. Esai Finalis GIS COMPETITION 2017, 1 (1), 1-3. https://doi.org/10.31227/osf.io/hx3mf.

Fajar, J. (2018). Dikukuhkan di New York, Jumlah Pulau Indonesia Kini Sebanyak. Retrieved January 9, 2018, from http://mogabay.co.id/2017/08/18/dikukuhkan-di-new-york,-jumlahpulau-indonesia-kini-sebanyak

FAO. (2014). The State of World Fisheries and Aquaculture: Opportunities and Challenges. Roma: United Nations.

Felson, M. (2006). Crime's Everyday Routines. Seminar of Midlands Centre for Criminology and the Criminal Justice, 16-20.

Hermes, R. (2014). Ecosystem Based Assessment and Management of the Indonesian Sea LME. An article at The 3rd Global LME Conference.

Hutabarat, S., \& Evans, S. M. (2014). Pengantar Oseanografi. Depok: UI Press.

Jaelani, A. K., \& Basuki, U. (2014). llegal Unreported and Unregulated (IUU) Fishing: Upaya Mencegah dan Memberantas Illegal Fishing dalam Membangun Poros Maritim Indonesia. Supremasi Hukum, 3 (1), 168-192. 
KKP RI. (2015). Statistik Kelautan dan Perikanan 2015. Jakarta: Pusat Data, Statistik, dan Informasi KKP RI.

Makkasau, K. (2012). Penggunaan Metode Analythical Hierarchy Processes (AHP) dalam Penentuan Prioritas Program Kesehatan (Studi Kasus Program Promosi Kesehatan). J@TI Undip, 7 (2), 105-112.

Marlina, \& Riza, F. (2013). Aspek Hukum Peran Masyarakat dalam Mencegah Tindak Pidana Perikanan. Jakarta: PT. Sofmedia.

Martin, K. S. (2004). GIS in Marine Fisheries Science and Decision Making. In Geographic Information Systems in Fisheries. Bethesda: American Fisheries Society.

Munaf, D. R., \& Sulistyaningtyas, T. (2015). Sistem Operasi Tersinergi Bakamla Sesuai dengan Undang - Undang Nomor 32 Tahun 2014 Tentang Kelautan. Jurnal Sosioteknologi, 14 (3), 273-288.

Pormar Indonesia. (2015). Mewujudkan Poros Maritim Dunia 2030. Retrieved January 8, 2018, from http://www.pormarindonesia.net/?page_id=137.

Ridho, M. R., Kaswadji, R. F., Jaya, I., \& Nurhakim, S. (2004). Distribusi Sumberdaya Ikan Demersal di Perairan Laut Cina Selatan. Jurnal Ilmu-Ilmu Perairan dan Perikanan Indonesia, 123-128.

Setiawan, I., Dede, M., Sugandi, D., \& Widiawaty, M. A. (2018). Investigating Urban Crime Pattern and Accessibility Using Geographic Information System in Bandung City. International Seminar on Tropical Eco-Settlements.

Suman, A., Wudianto, Sumiono, B., Badrudin, \& Nugroho, D. (2014). Potensi dan Tingkat Pemanfaatan Sumberdaya Ikan di Wilayah Pengelolaan Perikanan Republik Indonesia (WPP RI). Jakarta: Refika Grafika dan KKP RI.

Sutardi, D. (2015). Tak ada Tempat bagi Perampok Ikan. Majalah Mina Bahari, 1 (April-Juni).

Widiawaty, M. A., \& Dede, M. (2018). Pemodelan Spasial Bahaya dan Kerentanan Bencana Banjir di Wilayah Timur Kabupaten Cirebon. Jurnal Dialog Penanggulangan Bencana, 9 (2), 142-153. https://doi.org/10.31227/osf.io/kshb2.

Widiawaty, M. A., Dede, M., \& Ismail, A. (2018). Analisis Tipologi Urban Sprawl di Kota Bandung Menggunakan Sistem Informasi Geografis. Seminar Nasional Geomatika, 3 (1), 547-554. https://doi.org/10.24895/SNG.2018.3-0.1007. 